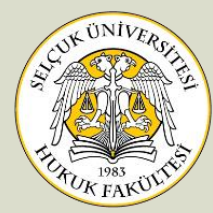

\title{
CRIMINAL RESPONSIBILITY ARISING FROM TRANSMITTING COVID-19 TO ANOTHER PERSON
}

\author{
Dr. Kübra TUNÇ*
}

Öz

A new phenomenon of our lives, COVID-19 has shown its effect in the way people commit crimes. For this reason, defining the criminal responsibility in COVID-19 related issues is a notable and significant matter. This study deals with the COVID-19 transmitting-related criminal issues that have been published in the media and aims to define criminal responsibility, potentially arises there. In the study firstly, the acts of COVID-19 transmission are generally analysed in terms of moral element of the perpetrator. Secondly, the suitability of the actus reus in terms of perpetrator, transmission act and victim is evaluated. Then, two real-life COVID-19 examples are examined by defining the offences committed and joinder relationship of these offences.

\section{Anahtar Kelimeler}

COVID-19 • Transmitting Coronavirus • Criminal Responsibility •

Contrariness to The Precautions Relating to Epidemics • Joinder of Offences

Araştırma Görevlisi, İstanbul Medeniyet Üniversitesi Hukuk Fakültesi Ceza ve Ceza Muhakemesi Hukuku Anabilim Dalı, İstanbul, Türkiye@®Research Asst., Istanbul Medeniyet University, Faculty of Law, Department of Criminal and Criminal Procedure Law, Istanbul, Turkey.

曰kubra.tunc@medeniyet.edu.tr•ORCID 0000-0002-2198-2838

Atıf Şekli | Cite As: TUNÇ Kübra, "Criminal Responsibility Arising from Transmitting Covid-19 to Another Person", SÜHFD., C. 29, S. 2, 2021, s. 1541-1556.

Intihal | Plagiarism: Bu makale intihal programında taranmış ve en az iki hakem incelemesinden geçmiştir. I This article has been scanned via a plagiarism software and reviewed by at least two referees. 


\title{
COVID-19 BULAŞTIRMADAN DOĞAN CEZA HUKUKU SORUMLULUĞU
}

\begin{abstract}
Hayatımızın yeni bir olgusu olan COVID-19, insanların suç işleme şeklini de etkilemiştir. Bu sebeple, COVID-19'a ilişkin olaylardaki ceza hukuku sorumluluğunu belirlemek önemli bir mesele teşkil etmektedir. Bu çalışma, medyada yer alan COVID-19 bulaştırma olaylarını ele almakta ve bu somut olaylardaki oluşması muhtemel ceza hukuku sorumluluğunu belirlemeyi amaçlamaktadır. Çalışmamızda öncelikle, COVID-19 bulaştırma eylemleri failin manevi unsuru açısından ele alınmaktadır. İkinci olarak ise, bulaştırma eylemlerinin fail, virüsü bulaştırma ve mağdur bakımından elverişliliği değerlendirilmektedir. Sonrasın-da ise, yaşanmış iki somut COVID-19 bulaştırma olayı, oluşması muhtemel suçların belirlenmesi ve bu suçların içtimaı hususunun değerlendirilmesi suretiyle incelenmektedir.
\end{abstract}

\section{Key Words}

COVID-19 • Koronavirüs Bulaştırma • Ceza Hukuku Sorumluluğu • Salgın Hastalıklara İlişkin Tedbirlere Aykırılık • Suçların İçtimaı

\section{INTRODUCTION}

COVID-19, i.e. new Coronavirus, is an infectious disease which arose in the city of Wuhan, China and spread to almost all countries of the world ${ }^{1}$. Incidents occurring around the World about transmitting COVID19 caused curiosity about criminal responsibility of the transmitting person. In this study, criminal responsibility of the COVID-19-transmitting person is examined with the help of real life examples.

\section{Incident Nr. 1}

A man, quarantined in a student dormitory after omrah visit to Saudi Arabia, rebelled as "Release me. I'm going to kill you all if it (COVID19) really exists. There is no doctor, no treatment, no release. You have put me in prison. Call the doctor, give me treatment, you have prisoned me. There is no treatment, nothing" and spitted around. The man also said "I'm going to make you all sick"2.

$1 \quad$ https://covid19bilgi.saglik.gov.tr/tr/covid-19-yeni-koronavirus-hastaligi-nedir (Date of Access 11.05.2020).

2 Umreden dönen amca ortalığı birbirine kattı: "Sizi de hasta edeceğim", günboyugazetesi.com.tr (Date of Access 22.04.2020). 


\section{Incident Nr.2}

A health worker allegedly spits on her neighbor's face in quarrel and says "I give people infected with coronavirus rides in ambulance all day. It's probably transmitted also to me; I will transmit it to you". Later on, the neighbor's COVID-19 diagnostic test came out positive, yet the health worker's negative ${ }^{3}$.

\section{GENERAL EVALUATION}

First of all, it is significant to state that transmitting an infectious disease to someone is not regulated as an offence in Turkish Criminal Code. Therefore, the acts of transmitting an infectious disease can be regarded as intentional/negligent homicide (Art 81,82,83,85 TPC), intentional/negligent injury (Art 86,88,89 TPC), aggravated injury (Art 87 TPC) in respect of the moral element of the perpetrator and the result of the act. Besides, other crimes such as insult (Art 125 TPC), duress (Art 106 TPC) etc. can also be regarded.

This study examines the criminal responsibility, arising from the acts (actus reus) relating to transmitting COVID-19 in regard to the moral element of perpetrator and suitability of the criminal act. Thereafter, possible joinder problems are also handled.

\section{A. Moral Element of the Perpetrator}

Moral element of the perpetrator is one of the issues to be examined in order to define the criminal responsibility of transmitting COVID-19. The criminal act of perpetrator, which is suitable to transmit COVID-19, might be performed to commit homicide or injury. First of all, the perpetrator has to know or estimate that $\mathrm{s} /$ he has the virus in order to have mens $r e a^{4}$. If the perpetrator's desire is killing the victim, when s/he transmits COVID-19, her/his responsibility shall be defined as intentional homicide. If the victim does not die after medical treatment, the responsibility shall be attempt to homicide.

3 https://www.haberler.com/tartistigi-saglik-calisaninin-yuzune-tukurdugunu13241121-haberi/ (Date of Access 20.5.2020).

4 ERDEM, Mustafa Ruhan, Cinsel İlişki Yoluyla Başkasına HIV Bulaştırmanın Cezalandırılabilirliği Sorunu, AÜEHFD, Vol VIII, Iss 1-2, 2004 (pp. 73-91), p.80. 
For sure, defining the moral element requires the examination of the all circumstances of the incident ${ }^{5}$. For mens rea, death or bodily harm of victim has to be inevitable or highly probable result of the perpetrator's actions ${ }^{6}$. The man in the Incident Nr.1 spat at people around after saying "I'll kill you all". In order to have mens rea for homicide, he has not only to know or estimate that he has COVID-19 but also to believe that he can kill others by spitting at them, i.e. he has to know or estimate that his act is suitable for homicide. Otherwise, his act cannot be regarded as an attempt to homicide. If his knowledge of having COVID-19 or suitability of his act cannot be determined, he may not be responsible for homicide according to the principle of in dubio pro reo.

Perpetrator can transmit COVID-19 in order to commit injury. In this case, if the victim shows symptoms, so if the act of transmitting is suitable in respect of victim, the criminal responsibility of perpetrator shall be defined as intentional injury. If the result is not only injury but also loss of any organ, loss or decrease in function of any organ or death, the criminal responsibility shall be defined as aggravated injury (Art 87 TPC). Yet, it is important to note that for the aggravated result, the perpetrator must have acted with at least negligence.

Perpetrator can transmit COVID-19 by violating the obligation of attention and care, in this case, s/he is responsible for the result with negligence. If perpetrator's act against to the obligation attention and care is suitable in terms of transmitting and the victim and this act causes injury, then s/he is responsible for negligent injury and if it causes death, then $\mathrm{s} /$ he is responsible for negligent homicide.

In order to accept that the perpetrator violates the obligation of attention and care, there must be such an obligation in advance. Violation of the precautions taken in the fight against COVID-19 is regarded as violation of the obligation of attention and care. The precautions can be

KOCA, Mahmut/ ÜZÜLMEZ, İlhan, Türk Ceza Hukuku Özel Hükümler, $6^{\text {th }}$ edn, Ankara, 2019, p. 87; ERDEM, p.81.

6 TAŞKIN, Ozan Ercan, Korunma Tedbiri Alınmaksızın Gerçekleşen Cinsel İlişki Yoluyla HIV Virüsünün Bulaştırılmasında Manevi Unsurun Belirlenmesi Sorunu, TBB Dergisi, Iss 79, 2008 (pp. 61-72), p.70. 
compulsory usage of mask and gloves, to keep social distance, self-quarantine, etc.

\section{B. Suitability}

Holding the perpetrator criminally responsible for transmitting COVID-19 to others depends on the suitability of the act in terms of the crimes mentioned above. Art 35 TPC regulates attempt to crime and adopts a holistic approach in evaluating the suitability of act. According to the preamble of Art 35 TPC, suitability of act is not evaluated only in terms of the tool used in crime, but also in terms of whole aspects of crime, including the object of the crime ${ }^{7}$. It is significant to note that, lack of suitability, i.e. attempt is unsuitable for any reason (unsuitability of perpetrator, object, tool, etc. ${ }^{8}$ ), perpetrator cannot be held responsible for attempt to crime. Because, TPC does not regulate criminal responsibility for unsuitable attempt.

\section{Suitability in terms of perpetrator}

Suitability in terms of perpetrator can vary in accordance with the offence. For instance, a COVID-19 carrier is suitable to commit the offence of homicide or injury. On the other hand, a non-carrier of COVID-19 is not suitable to commit homicide or injury by causing bodily harm ${ }^{9}$. A non-carrier of COVID-19 can commit other offences such as duress or insult by typical acts of transmission, e.g. spit.

\section{Suitability in terms of actus reus of transmitting COVID-19}

Another issue to be checked for suitability is the suitability of transmission act. Since COVID-19 spreads via respiratory droplets, spitting, coughing and sneezing acts can be accepted suitable in this respect.

7 Ankara HBV Üniversitesi Türk Ceza Hukuku Uygulama ve Araştırma Merkezi, Türk Ceza Hukuku Mevzuatı Cilt 1 (Kanunlar), 22 ${ }^{\text {nd }}$ edn, Ankara, 2018, p. 191.

8 Unsuitability of act can be classified as unsuitability resulting from the object of offence, unsuitability of tool, double unsuitability in terms of both object and tool of offence and unsuitability resulting from perpetrator (KAZAKER, Gözde, Ceza Hukukunda Elverişsiz Teşebbüs, Ankara, 2019, p. 224). Normally unsuitability of victim is examined under the title of unsuitability of object of offence. Yet, unsuitability of victim in case of COVID19 is sui generis form of unsuitability and is not mentioned in any examples relating to unsuitability.

9 A non-carrier of COVID-19 is suitable to commit injury by causing a mental harm. 
Besides, regarding the lasting time of COVID-19 on surfaces, handing over a tissue, that has been sneezed into the day before, is not suitable to transmit COVID-19.

\section{Suitability in terms of victim}

In order COVID-19 transmission to be suitable for the offences that perpetrator aims to commit, victim must be suitable for these offences. Not each COVID-19 transmission case results in homicide, injury or aggravated injury. What defines these results is immunity system of the victim as well as the strength of the virus. So, COVID-19 causes mild to moderate symptoms in many healthy persons and more severe symptoms such as loss of organ or organ's function or death in persons who has weaker immunity due to age, chronic disease or any other reason.

That's why, spitting on a healthy person with intent for homicide cannot be held suitable for intentional homicide. In this case, the criminal responsibility of the perpetrator shall be intentional injury if victim presents any symptoms. Because, the act of perpetrator is only suitable for injury but not homicide. Even the will of the perpetrator is to murder but not to injure, the rule of "more contains the less" applies here and intent for homicide is accepted to contain intent for injure.

The special information about victim must be taken into account by defining the suitability. For example, a simple act of injury is suitable for homicide when the victim suffers from hemophilia ${ }^{10}$. However, if perpetrator does not know this fact, $\mathrm{s} /$ he is no longer responsible for the results arising from it ${ }^{11}$.

10 ÖZGENÇ, İzzet, Türk Ceza Hukuku Genel Hükümler, 14 $4^{\text {th }}$ edn, Ankara, 2018, p. 499.

11 See the case that the perpetrator was not held responsible for intentional homicide, rather negligent homicide because there is no certain proof that he knew the heart disease of the victim (Ceza Genel Kurulu (Grand Penal Chamber, Abbreviated as GPC), File Nr. 2015/695, Decision Nr. 2019/128, 26.02.2019, <karararama.yargitay.gov.tr> Date of Access 9.6.2020). 


\section{INCIDENT ANALYSES}

\section{A. Incident Nr. 1}

\section{Offences committed in the case}

The man in the incident threatened others with transmitting COVID-19 and spat around. As is not known whether the man carries COVID-19 or not, criminal responsibility of him shall be defined according to assumptions.

a) If the man does not carry COVID-19, it is not possible for him to commit homicide via COVID-19 transmission. Since his transmitting acts such as spitting etc. are not suitable for homicide. His transmitting acts are not also suitable for injury by causing bodily harm. Intentional injury is regulated in Art 86 TPC as "Person intentionally giving harm or pain to another person or executes an act which may lead to deterioration of health or mental power of others, is sentenced to imprisonment from one year to three years $^{\prime \prime 2}$. The acts of injury do not have to cause a concrete bodily harm. It is enough to cause a mental confusion ${ }^{13}$. Injury can be either physical or physiological ${ }^{14}$. As a result, spit of the perpetrator can be thought of injury, as spit may cause victim to suffer physiologically.

b) If the man carries COVID-19, the suitability of his acts to transmit COVID-19 should be examined in respect of intentional homicide, intentional injury or aggravated injury. The suitability must be defined in accordance with the immune system of victims. If victim is old, sick of suffers from a chronic disease, transmitting COVID-19 can be regarded as suitable to commit homicide. However, if victim is healthy, transmitting COVID-19 can be regarded as suitable to commit only injury. The moral element of perpetrator is intent for homicide, and as a result of the general principle of "more contains the less", his moral element is regarded to be

\footnotetext{
12 For translation see https://www.wipo.int/edocs/lexdocs/laws/en/tr/tr171en.pdf (Date of Access 06.06.2020).

13 ÖZBEK, Veli Özer/ DOĞAN, Koray/ BACAKSIZ, Pınar, Türk Ceza Hukuku-Özel Hükümler, 14 ${ }^{\text {th }}$ edn, Ankara, 2019, p. 205.

14 SOYASLAN, Doğan, Ceza Hukuku Özel Hükümler, 11 $1^{\text {th }}$ edn, İstanbul, 2016, p. 155.
} 
intent for injury ${ }^{15}$. It is important to note that in case victim presents no symptoms at all, the act is not suitable for injury.

Whether or not victim suffers from a disease and the disease can be recognized by the perpetrator does not make any difference in this case, since perpetrator has already presented his intention for homicide by his actions and words.

c) Regardless of whether or not the man carries COVID-19, his act of threatening may constitute the offence of duress (Art 106 TPC) and his act of spitting may constitute insult (Art $125 \mathrm{TPC}$ ). Offence of duress is regulated in Art $106 \mathrm{TPC}$ as "to threaten another person with an assault to life, bodily or sexual integrity of her/himself, her/his close acquaintances or someone else". Since it is not known by others that whether or not the man carries COVID-19, threatening with homicide has an effect on victims' willpower and that's why his threat is suitable for the offence of duress (Art 106 TPC).

The spit of perpetrator can be thought to constitutes the offence of insult. The offence of insult, stated in Art 125 TPC, is defined as "attacking another person's honor, dignity and good reputation by attributing facts which are able to harm her/his honor, dignity and good reputation or reviling". The offence of insult can be committed only with specific types of acts which are attributing specific facts and reviling. Yet, reviling does not have a specific form ${ }^{16}$. So, spitting can be regarded as an act of insult, since act of

15 Turkish Court of Cassations also reaches the same result in its decisions by applying the rule in dubio pro reo. When there is a doubt whether perpetrator has intent for homicide or not in a case s/he attacks victim, the court decides that s/he has intent for injury by using the rule in dubio pro reo (GPC File Nr. 2019/59, Decision Nr. 2019/493, 25.06.2019; GPC File Nr. 2014/253, Decision Nr. 2015/46, 17.05.2015, Date of Access < karararama.yargitay.gov.tr $>9.6 .2020$ ).

16 ÖNDER, Ayhan, Şahıslara ve Mala Karşı Cürümler ve Bilişim Alanında Suçlar, İstanbul, 1994, p. 243; TEZCAN, Durmuş/ ERDEM, Mustafa Ruhan/ ÖNOK, Murat, Teorik ve Pratik Ceza Özel Hukuku, 17th edn, Ankara, 2019, pp. 607-608; ARTUÇ, Mustafa, Kişilere Karş1 Suçlar, 2 ${ }^{\text {nd }}$ edn, Ankara, 2018, pp. 1323, 1337-1338. "Insult is a statement of thought. Yet it is not committed via words all the time. Sometimes it can be committed via actions. Such as giving someone the middle finger, tearing a petition or report and throwing it into the face of an officer or throwing cash in to the face of an officer (p.1323)"; ÜZÜLMEZ, İlhan, "Hakaret Suçu”, Ceza Hukuku Dergisi (CHD), Vol 5, Iss 12, 2010 (pp. 41-71), p. 41, p. 50, "Reviling does not have a specific form. It can be performed via writing, saying, picture, sign or action" (ÜZÜLMEZ, p. 50); ÖZEN, 
spitting is able to harm someone's honor, dignity and good reputation. If the victims are public officers, aggravated version of insult applies (Art 125/3-a). Besides, insult is made in public, which also another aggravated version of insult (Art 125/4).

Finally, the offence of contrariness to the precautions relating to epidemics (Art 195 TPC) shall also be examined in this case, since the incident emerged in quarantine. Art 195 TPC states that "Any person who refuses to comply with the precautions imposed by the authorized bodies at places under quarantine to avoid spread of disease from an ill or death person, is punished with imprisonment from two months to one year."17. The acts of threatening and spitting out violate the quarantine precautions and compose the offence stated in Art 195 TPC.

\section{The joinder of offences ${ }^{18}$ issue}

Under this title firstly the joinder of offence among the offences of duress, injury/homicide and insult must be examined according to two probabilities.

a) If the act of transmitting COVID-19 is suitable for intentional or aggravated injury or intentional homicide, he will be responsible only for these offences. Act of threatening can be regarded as "unpunished previous act" in the scope of supposed joinder of crimes (görünüşte içtima) ${ }^{19}$.

Mustafa, "Hakaret Suçu ve İnternet Yoluyla İşlenmesi”, TBB Dergisi, Iss 75, 2008 (pp.94-108), p. 94, "In a crowded and prestigious meeting, leaving a question unanswered can be regarded as insult to the person who asked the question." (ÖZEN, p. 97); SINAR, Hasan, “Türk Ceza Kanunu'nda Hakaret Suçu ve Bu Suçun Karşılaştırmalı Hukukta Gelişen Hakaretin Suç Olmaktan Çıkartılması Eğilimi Yönünden Değerlendirilmesi", CHD, Vol 9, Iss 24, 2004 (pp. 75-119), pp. 75, 84.

17 For translation see https://www.wipo.int/edocs/lexdocs/laws/en/tr/tr171en.pdf (Date of Access 05.06.2020).

18 The term of joinder of offences contains several terms, which are joint offences (Art $42 \mathrm{TPC}$ ), successive offences (Art 43/1 TPC), ideal concurrence among the same types of crime (Art 43/2 TPC) and ideal concurrence among the different types of crime (Art 44 TPC). For the usage of the terms ideal concurrence among the same types of crime and ideal concurrence among the different types of crime see DEMIREL, Muhammed/ KARTAL, Melik, “The Conditions for the Application of Successive Crime in the Turkish Criminal Code", Istanbul Hukuk Mecmuası, Vol 77, Iss 1, 2019 (pp.451-461), pp. 451, 452.

19 Özbek, Doğan and Bacaksız also states that in case of a threat to injury and act of injury in succession, the perpetrator shall be responsible for only injury. However, the 
Moreover, suitable act of injury/homicide can also cause offence of insult. Since a single act of spitting causes more than one crime, the perpetrator shall be responsible for the crime that requires a heavier punishment as Art 44 TPC states.

Furthermore, joinder of offences between the offence of contrariness to the precautions relating to epidemics (Art 195 TPC) and injury/homicide must be examined. According to our opinion, there is a primary norm-subsidiary norm relationship, which is a form of supposed joinder of offences, between offence of contrariness to the precautions relating to epidemics (Art 195 TPC) and the other offences.

There are two reasons of this opinion:

1) The offence of contrariness to the precautions relating to epidemics (Art 195 TPC) is an offence of danger. Since there is a primary normsubsidiary norm relationship between offences of danger and offences of harm ${ }^{20}$, in case of that an act constitutes both an offence of harm and an offence of danger, offence of harm (the primary norm) must be applied ${ }^{21}$.

authors claims that in case of a threat to homicide and act of injury in succession, the perpetrator shall be responsible for both threat and injury

(ÖZBEK/DOĞAN/BACAKSIZ, p. 413). Additionally, it is important to note that the act of spitting was not performed by aiming threat but homicide. For this reason, there is no way to apply Art 106/3 even if both duress and injury are accepted to be committed and Art 44 applies.

20 HAKERİ, Hakan, Ceza Hukuku Genel Hükümler, 23 ${ }^{\text {nd }}$ edn, Ankara, 2020, p. 642; DOĞAN, Koray, "Tehlike Suçu ile Zarar Suçu Arasındaki Suçların İçtimaı Sorunu”, TAAD, Iss 16, 2014 (pp. 179-208), pp. 179, 198; DEMIREL, Muhammed, “Karar Analizi Tehlike Suçları- Zarar Suçları Arasındaki İlişkinin İçtima Kuralları Kapsamında Değerlendirilmesi", Journal of Istanbul University Law Faculty, Vol 71, Iss 1, 2013 (pp. 1479-1488), pp. 1479, 1485. Hakeri also states that even he does not agree with, it is possible to admit the existence of joinder of offences and application of Art 44 TPC in this case (HAKERI, p. 642). To constitute primary norm-subsidiary norm relationship between offence of danger and offence of harm, protected legal values of the offences should be totally or partially the same. Yet, if the victims are not the same, it is not possible to constitute primary norm-subsidiary norm relationship between the offence of danger and offence of harm. For instance, if the victim of the offence of danger is society and the victim of the offence of harm is an individual, there is no primary norm -subsidiary norm relationship between these offences. In the case of different victims, if the offences are committed by a single act, joinder of offences should be applied (DOĞAN, p. 199).

${ }_{21} \quad \dot{I}_{c ̧ e l}$ asserts that in case of primary-subsidiary norm relationship (a form of supposed joinder of offences), it is not important whether the offences are results of a 
For instance, if quarantine precautions are violated by an act such as coercion or threat to public officers, not the offence in Art 195 but interference with public duty (Art 265 TPC) is composed ${ }^{22}$. Similarly, if quarantine precautions are violated by transmitting an epidemic disease, not the offence in Art 195, but intentional or negligent injury is composed ${ }^{23}$.

2) Protected legal values of these offences partially the same ${ }^{24}$. The protected legal value of Art 195 (offence of danger) is public health and the protected legal values of homicide or injury (offences of harm) are life and body integrity. The protected legal values of these offences are the same in part. For that reason, primary norm-subsidiary norm

single act or multiple acts. What's important in this case is that there are more than one offences which seem to be applicable, indeed only one of them is really applicable (İÇEL, Kayıhan, Suçların İçtimaı, İstanbul, 1972, p. 211.

22 YAŞAR, Osman/ GÖKCAN, Hasan Tahsin/ ARTUÇ, Mustafa, Yorumlu-Uygulamalı Türk Ceza Kanunu 4. Cilt (Md.141-196), 2 ${ }^{\text {nd }}$ edn, Ankara, 2014, pp. 6037-6038.

23 YAŞAR/ GÖKCAN/ ARTUÇ, p. 6039; YENERER ÇAKMUT, Özlem, “Bulaşıcı Hastalıklara İlişkin Tedbirlere Aykırı Davranma Suçu (TCK m.195)" in Prof. Dr. Feridun Yenisey'e Armağan C.I (İstanbul, 2014, pp. 543-553), p. 550; KANGAL, Zeynel, "Bulaşıcı Hastalıklara İlişkin Tedbirlere Aykırı Davranma" in Özel Ceza Hukuku Cilt V (İstanbul, 2019, pp. 433-450) p. 447. Doğan asserts that there can be no primary norm-subsidiary norm relationship between intentional offences and negligent offences. Because for this kind of relationship, there must be a temporal sequence between these offences which does not exist in between intentional offences and negligent offences. Moreover, in primary norm-subsidiary norm relationship, even the perpetrator causes two offences, it is unnecessary and impossible to apply both at the same time. It is not valid for the relationship between intentional offences and negligent offences (DOĞAN, p. 198). Kangal accepts the responsibility for a single offence when the perpetrator leaves quarantine (Art 125 TPC) and transmits a disease to another person (depends on the moral element, Art 86-88 or 89). However, he claims also that in case the perpetrator violates the precautions of quarantine by insulting the competent public officers, s/he shall be punished with aggravated insult as a result of joinder of offences (KANGAL, p. 447).

24 In doctrine there is a view that asserts in order to constitute primary norm-subsidiary norm relationship between offence of danger and offence of harm, protected legal values of the offences should be totally or partially the same (Doğan, p. 198). However, the same author claims that if the victims are not the same, it is not possible to constitute primary norm-subsidiary norm relationship between the offence of danger and offence of harm. For instance, if the victim of the offence of danger is society and the victim of the offence of harm is an individual, there is primary norm subsidiary norm relationship between these offences. In the case of different victims, if the offences are committed by a single act, joinder of offences (Art 44 TPC) should be applied (DOĞAN, p. 198). 
relationship is to be constituted between offence of contrariness to the precautions relating to epidemics and intentional homicide and injury.

Additionally, if there is more than one victim in the incident, application of ideal concurrence among the same types of crime (Art 43/2 TPC) can be thought. However, as Art 43/3 states, in case of intentional injury and homicide the institution of ideal concurrence among the same types of crime does not apply.

b) If the act of transmitting COVID-19 is unsuitable for intentional or aggravated injury or intentional homicide, acts of threatening and spitting can be regarded as a single act in terms of law, since the acts have been performed in succession at the same place and are the outputs of the same will. In this instance, both duress (Art 106 TPC) and insult (Art 125 TPC) are committed by a single act in terms of law. Moreover, this lawfully single act violates the precautions relating to epidemics (Art 195 TPC) as well. Since all offences of duress, insult and contrariness to precautions relating to epidemics are crimes of danger, there is no need to examine supposed joinder of crimes like it has been done above. As Art 44 TPC states, perpetrator is punished with the offence of aggravated insult in public (Art 125/3-a \& Art 125/4 TPC), which foresees a heavier punishment.

In addition, if there is more than one victim, also the institution of ideal concurrence among the same types of crime (Art 43/2 TPC) applies, because with a single act of insult, more than one crime is committed.

\section{B. Incident Nr. 2}

\section{Offences committed in the case}

It is remarkable that the COVID-19 diagnostic test of the perpetrator came out negative. Actually, it does not mean that the perpetrator has never carried COVID-19, but it only means that in the time of the test was made, she did not carry it. To be sure, COVID-19 antibody test shall be made in order to find out whether she has ever carried COVID-19 or not. Since it is a matter of evidence, we assume that she has never carried COVID-19 and analyze the incident according to this assumption.

Since the health worker in Incident Nr.2 has tested negative for COVID-19, she cannot commit homicide by transmitting COVID-19, i.e. 
the perpetrator is unsuitable in order to commit homicide by transmitting COVID-19. As a result, responsibility for attempt to homicide cannot be accepted because TPC does not provide a punishment for an unsuitable attempt. As Art 35 TPC states, for attempt to crime, the act must be suitable and the act can be punishable as soon as it is suitable in terms of a crime. However, she can be regarded suitable for injury, as spit may cause victim to suffer physiologically which is addressed as deterioration of health or mental power in Art 86 TPC $^{25}$.

Moreover, spit of perpetrator can be thought to constitutes the offence of insult, since act of spitting is able to harm someone's honor, dignity and good reputation.

Besides, she said to the victim "I'll transmit it to you" and threatened the victim with giving harm to her life and body integrity which constitutes the offence of duress (Art 106 TPC).

\section{The joinder of offences issue}

Act of spitting can be thought in the context of insult. Here, one act of spitting causes two offences, intentional injury and insult, so according to ideal concurrence among the different types of crime provision, Art 44 TPC, perpetrator shall be punished with the offence which requires heavier punishment, intentional injury in the incident.

Moreover, the sentence "I'll transmit it to you" constitutes offence of duress in principle. Yet, in the incident it should be regarded as "an unpunished previous act", a form of supposed joinder of offence, because she first threatened and then, did what she had threatened about ${ }^{26}$. The perpetrator shall be responsible for only intentional injury ${ }^{27}$.

25 The concept of deterioration of health contains the concept of deterioration of mental power in terms of meaning. There is not necessary to state the phrase of "deterioration of mental power" in the article, but only a repetition (CENTEL, Nur/ ZAFER, Hamide/ ÇAKMUT, Özlem, Kişilere Karşı İşlenen Suçlar Cilt:I, $4^{\text {th }}$ edn, İstanbul, 2017, p. 142).

26 It should be noted that, intentional injury is not performed in order to threaten in this case, for that reason, there is no way to apply Art 106/3 TPC.

27 Özbek, Doğan and Bacaksız also states that in case of a threat to injury and act of injury in succession, the perpetrator shall be responsible for only injury. However, the authors claims that in case of a threat to homicide and act of injury in succession, 


\section{CONCLUSION}

Real-life examples about COVID-19 may cause several criminal questions relating to moral element, suitability and joinder of offences. These questions are examined meticulously in the study, by giving general and incident-based evaluations.

Incident Nr. 1 deals with a man in a COVID-19 quarantine, who threatens and spits around. His criminal responsibility is defined in accordance with whether or not he carries COVID-19. If he has COVID-19, then his act of spitting is suitable for intentional homicide/injury or aggravated injury according to the suitability of the victims. In this case, his act of threatening relating to killing must regarded as "unpunished previous act", evaluated under supposed joinder of offences. Additionally, there is a primary norm-subsidiary norm relationship, which is a form of supposed joinder of offences between the intentional homicide/injury or aggravated injury and the offence of contrariness to the precautions relating to epidemics (Art 195 TPC). Even if the perpetrator does not have COVID-19, his act of spitting can be held suitable in terms of intentional injury, as long as it injures the victims physiologically. Besides, his act constitutes offences of duress and insult and Art 44 TPC applies.

Incident Nr. 2 deals with a woman who spitted on her neighbor's face. The perpetrator's COVID-19 diagnostic test came out negative while her neighbors' positive. Since the perpetrator does not have COVID-19, she is not suitable to transmit it to anybody. However, her act may cause a physiological pain, that's why it is regarded as an act of injury. Her threat to transmit COVID-19 must be also regarded as an "unpunished previous act", as she did what she had threatened before. 


\section{KAYNAKLAR}

Ankara HBV Üniversitesi Türk Ceza Hukuku Uygulama ve Araştırma Merkezi, Türk Ceza Hukuku Mevzuatı Cilt 1 (Kanunlar), 22 ${ }^{\text {nd }}$ edn, Ankara, 2018.

ARTUÇ, Mustafa, Kişilere Karşı Suçlar, $2^{\text {nd }}$ edn, Ankara, 2018.

CENTEL, Nur/ZAFER, Hamide/ÇAKMUT, Özlem, Kişilere Karşı İşlenen Suçlar Cilt:I, $4^{\text {th }}$ edn, İstanbul, 2017.

DEMIREL, Muhammed, “Karar Analizi Tehlike Suçları- Zarar Suçları Arasındaki İlişkinin İçtima Kuralları Kapsamında Değerlendirilmesi", Journal of Istanbul University Law Faculty, Vol 71, Iss 1, 2013 (pp. 1479-1488), https://dergipark.org.tr/tr/pub/iuhfm/issue/9188/115226 (Date of Access 6.6.2020).

DEMIREL, Muhammed/ KARTAL, Melik, "The Conditions for the Application of Successive Crime in the Turkish Criminal Code", Istanbul Hukuk Mecmuasi, Vol 77, Iss 1, 2019 (pp. 451-461).

DOĞAN, Koray, “Tehlike Suçu ile Zarar Suçu Arasındaki Suçların İçtimaı Sorunu", TAAD, Iss 16, 2014 (pp. 179-208).

ERDEM, Mustafa Ruhan, Cinsel İlişki Yoluyla Başkasına HIV Bulaştırmanın Cezalandırılabilirliği Sorunu, AÜEHFD, Vol VIII, Iss 1-2, 2004 (pp. 73-91).

HAKERİ, Hakan, Ceza Hukuku Genel Hükümler, 23 ${ }^{\text {nd }}$ edn, Ankara, 2020. İÇEL, Kayıhan, Suçların İçtimaı, İstanbul, 1972.

KANGAL, Zeynel, "Bulaşıcı Hastalıklara İlişkin Tedbirlere Aykırı Davranma" in Özel Ceza Hukuku Cilt V (İstanbul, 2019, pp. 433-450).

KAZAKER, Gözde, Ceza Hukukunda Elverişsiz Teşebbüs, Ankara, 2019.

KOCA, Mahmut/ ÜZÜLMEZ, İlhan, Türk Ceza Hukuku Özel Hükümler, $6^{\text {th }}$ edn, Ankara, 2019.

ÖNDER, Ayhan, Şahıslara ve Mala Karşı Cürümler ve Bilişim Alanında Suçlar, İstanbul, 1994.

ÖZBEK, Veli Özer/ DOĞAN, Koray/ BACAKSIZ, Pınar, Türk Ceza Hukuku-Özel Hükümler, 14 ${ }^{\text {th }}$ edn, Ankara, 2019.

ÖZEN, Mustafa, “Hakaret Suçu ve İnternet Yoluyla İşlenmesi”, TBB Dergisi, Iss 75, 2008 (pp. 94-108).

ÖZGENÇ, İzzet, Türk Ceza Hukuku Genel Hükümler, $14^{\text {th }}$ edn, Ankara, 2018. 
SINAR, Hasan, "Türk Ceza Kanunu'nda Hakaret Suçu ve Bu Suçun Karşılaştırmalı Hukukta Gelişen Hakaretin Suç Olmaktan Çıkartılması Eğilimi Yönünden Değerlendirilmesi", CHD, Vol 9, Iss 24, 2004 (pp. 75-119).

SOYASLAN, Doğan, Ceza Hukuku Özel Hükümler, $11^{\text {th }}$ edn, İstanbul, 2016.

TAŞKIN, Ozan Ercan, Korunma Tedbiri Alınmaksızın Gerçekleşen Cinsel İlişki Yoluyla HIV Virüsünün Bulaştırılmasında Manevi Unsurun Belirlenmesi Sorunu, TBB Dergisi, Iss 79, 2008 (pp. 61-72).

TEZCAN, Durmuş/ ERDEM, Mustafa Ruhan/ ÖNOK, Murat, Teorik ve Pratik Ceza Özel Hukuku, 17 th edn, Ankara, 2019.

ÜZÜLMEZ, İlhan, "Hakaret Suçu”, Ceza Hukuku Dergisi (CHD), Vol 5, Iss 12, 2010 (pp. 41-71).

YAŞAR, Osman/ GÖKCAN, Hasan Tahsin/ ARTUÇ, Mustafa, YorumluUygulamalı Türk Ceza Kanunu 4. Cilt (Md.141-196), $2^{\text {nd }}$ edn, Ankara, 2014.

YENERER ÇAKMUT, Özlem, “Bulaşıcı Hastalıklara İlişkin Tedbirlere Aykırı Davranma Suçu (TCK m.195)" in Prof. Dr. Feridun Yenisey'e Armağan C.I (İstanbul, 2014, pp. 543-553).

https://covid19bilgi.saglik.gov.tr/tr/covid-19-yeni-koronavirus-hastaliginedir (Date of Access 11.05.2020).

https://jurix.com.tr.

https://karararama.yargitay.gov.tr.

Umreden dönen amca ortalığı birbirine kattı: "Sizi de hasta edeceğim" günboyugazetesi.com.tr (Date of Access 22.04.2020).

https://www.haberler.com/tartistigi-saglik-calisaninin-yuzune-tukurdugunu-13241121-haberi/(Date of Access 20.5.2020).

https://www.wipo.int/edocs/lexdocs/laws/en/tr/tr171en.pdf (Date of Access 06.06.2020). 